\title{
Logistics Innovation in China: The Lens of Chinese Daoism
}

\author{
Yu Gong ${ }^{1}$, Lujie Chen ${ }^{2}$, Fu Jia ${ }^{3, *} \mathbb{C}$ and Richard Wilding ${ }^{4}(\mathbb{D}$ \\ 1 Southampton Business School, University of Southampton, Southampton, Hampshire SO17 1BJ, UK; \\ y.gong@soton.ac.uk \\ 2 International Business School Suzhou, Xi'an Jiaotong-Liverpool University, Suzhou 215123, China; \\ lujie.Chen@xjtlu.edu.cn \\ 3 School of Economics and Management, Minjiang University, Fuzhou 350108, China \\ 4 Cranfield School of Management, Cranfield, Bedfordshire MK43 0AL, UK; richard.wilding@cranfield.ac.uk \\ * Correspondence: fu.jia@york.ac.uk
}

Received: 1 November 2018; Accepted: 17 January 2019; Published: 21 January 2019

check for updates

\begin{abstract}
Innovation is vital for the logistics industry. This paper develops a Daoism-based conceptual model for logistics innovation in China. It identifies research gaps in this area and provides directions for future research. Following a content-based literature review methodology, 45 studies were selected. We identified five research themes: interpretation of logistics innovation; Chinese institutional environment for logistics innovation; innovation generation; innovation adoption; and innovation capability. We integrate the process view and outcome view of logistics innovation and propose that logistics capability, as an innovation outcome, is reflected and measured by innovation generation and adoption. This study is probably one of the first conceptual development papers on logistics innovation in China, providing a model for innovation within this context. It provides new avenues of research in this emerging, albeit important, area of research. Our conceptual framework utilizes Chinese Daoism philosophical thinking to provide a new lens for logistics innovation that is sensitive to the cultural environment.
\end{abstract}

Keywords: logistics innovation; China; conceptual development; innovation capability; Daoism

\section{Introduction}

Over four decades of economic development in China, the Chinese logistics industry has undergone accelerating development. As the Chinese National Development and Reform Commission (NDRC, [1]) states, in 2017 the total value of China's logistics industry was 252.8 trillion Yuan (approximately USD1 = RMB6.5), around 6.8\% more than in 2016. The total logistics costs in 2017 amounted to 12.1 trillion Yuan, a year-on-year increase of $9.2 \%$. The ratio of total logistics costs to gross domestic product (GDP) was 14.6\%, a 0.3\% decrease from 2016 [1].

Compared with other countries, logistics has been a priority industry in China's economic development. According to the 'Medium and long-term development of logistics industry planning (2014-2020)', the logistics industry is "fundamental and strategic to the country's economic development" [2].

China's entry into the World Trade Organization (WTO) at the end of 2001 boosted the country's logistics industry. Although the speed of its logistics development slowed down from a double-digit level to $6.7 \%$ in 2015, overall it has shown a higher growth rate than the level of GDP growth most of the time. However, China's total logistics costs remain high and the ratio of logistics costs to GDP remains almost double that of many developed countries [3].

A highly fragmented logistics market and a low penetration of third-party logistics (3PLs or TPLs) are two reasons for China's high logistics costs [4]. Further, China has a slow adoption rate for 
new technologies, exacerbating the situation [5]. While some customers (retailers and manufacturers) complain about lack of innovation with regard to 3PLs, other customers try to squeeze the profit margin of 3PLs, making innovation even more difficult-although all parties realize that it is important for logistics providers to provide value-added service to their customers and ensure the efficiency of the supply chain.

To survive in such fierce competition, logistics companies need to search constantly for new ways to serve their clients and improve their service quality [6], especially as the Chinese economy has now entered a 'new norm' of slower economic growth. These firms need to differentiate themselves through innovation and to provide customized services to fulfil even more complex customer needs [7].

Logistics and supply chain researchers have recognized the importance of the national culture in the buyer-supplier relationship [8]. Zhao et al. [9] call for research on the effect of guanxi (an informal network based on kinship and friends) on buyer-supplier relationships in China. Lai et al. [10] propose more cross-cultural investigation of the moderating effects of culture on the effects of power on relationship commitment and supply chain integration. Miao et al. [11] suggest that organizational culture is positively associated with firms' social responsibility. Barney et al. [12] conclude that national cultures and philosophical inspiration such as Daoism, Confucianism, Hinduism, and Buddhism have a specific moderating or mediating role on innovation and which lead to the differentiation between countries and regional ecologies.

Given the importance of logistics innovation, this paper aims to develop an integrated conceptual model by conducting a content-based literature review of this topic in China for the following reasons: first, the rapid development in China's logistics industry provides many opportunities for innovation. It has taken China only around 40 years to achieve the level of accomplishment in industrialization that took developed countries 100 years [13]. Hence, China can be a large-scale laboratory for logistics innovation. Second, China has been the largest manufacturing base in the world for many years and is a rapidly developing consumer market; therefore, Chinese logistics practices have a significant influence on the effectiveness and efficiency of global supply chains [14,15]. Last, we answer the call by Liu and Mckinnon [16] to create China-based supply chain management knowledge because China has a different institutional environment and faces different supply chain challenges (e.g., economic, political, and cultural) from those of the West. There are hardly any reviews on logistics innovation in general $[17,18]$ and there are none specifically for China. This situation provides an excellent opportunity for applying, extending, and challenging existing theories and frameworks that have been developed in the West [19].

In particular, this study pays attention to the Chinese philosophy of Daoism, as "contemporary Chinese business life reflects more the philosophy of Daoism rather than Confucianism" [20] (p. 439). Daoism says, "The things of the world arise from being. And being arises from nothing" (Dao-de-jing Chapter 40) [21]. This plays an important role shaping logistics innovation in China. For example, Birkin et al. [22] find that new sustainable business models can be generated from the traditional Chinese cultural approach, such as Daoism. Sabelli [23] claims that Daoism highlights the co-existence of opposites (e.g., harmony and conflict, existence and non-existence, union, and separation); interacting opposites co-create novelty, complexity and diversity; opposites are complementary and can be unionized. This is also called the Yin-Yang principle, a Chinese form of dualism, which argues that two states co-exist in harmony and can be in transition from Yin to Yang (and vice versa) all the time [24], which can potentially be applied to the relationship between innovation generation and innovation adoption.

Based on the above arguments, we believe that a systematic literature review is therefore needed to synthesize the research that has already been conducted and to provide directions for future research. This research aims to answer the research questions:

- What are the research themes in logistics innovation in China?

- How can the Chinese philosophy of Daoism be applied to logistics innovation in China?

- What are the future research directions for logistics innovation in China? 
The remainder of this paper is arranged as follows. We begin by presenting our literature review and then we report the descriptive results. Next, we analyze the extracted logistics innovation themes and follow this with a proposed conceptual model of logistics innovation built on the traditional Chinese philosophy of Daoism, as well as presenting a discussion of future research direction. Finally, we provide a conclusion on the implications and limitations of this research.

\section{Review Method}

To identify the papers on logistics innovation in China, we adopted a content-based literature review method [25]. A content-based literature review applies content analysis tools and is considered a branch of systematic literature reviews [26]. The dimensions and analytic categories can be deductive (based on theories) or inductive (based on reviewed material). We adopted a framework combining key constructs from Grawe [17] and Busse and Wallenburg [18] following a deductive approach and then revised the initial framework with the themes inductively identified from the reviewed papers. Finally, we proposed a conceptual framework for logistics innovation in China.

To specify the scope of the review, we defined the boundaries. For a definition of 'China', we followed Cui et al. [27] and Liu [28], which indicated the Great China Region covering mainland China, Hong Kong and Taiwan (since the latter two are closely linked to mainland China historically, culturally and economically). Logistics are the activities between customers and suppliers that are involved in the flow of products, service and information from the point of origin to the point of consumption [29]. This includes the traditional logistics services such as transportation and warehousing, as well as value-added services such as vendor management inventory and logistics information tracking. Logistics innovation includes all logistics-related innovations. These can be innovations by the logistics industry or other industries, logistics service users or logistics providers, as long as the innovations have a direct influence on logistics activities [30]. We adopted this definition of logistics innovation in this paper.

To begin the review process, three sets of keywords were identified for logistics, innovation and China, respectively. Since the terms 'logistics' and 'China' are relatively straightforward, the keywords applied were 'logistics' and 'China/Chinese/Taiwan/Taiwanese/Hong Kong'. As 'innovation' is a broad term, the keywords used were 'innovat*/change/evolut*/trend/develop*/improv*/solution"'.

'EBSCO' and 'Scopus' were applied as the search engines. These databases were selected because of their broad coverage of management and engineering journals and their wide accessibility by worldwide library systems. In addition, they have been widely applied in other logistics and supply chain literature reviews. To be comprehensive, we did not apply a beginning year or specify the journals; rather, we specified peer-reviewed papers published in English language journals, to the end of 2016 and with a focus on logistics innovation in the Great China Region.

After entering the three sets of keywords in the two databases, under 'Abstract or Author-applied abstract' in EBSCO and 'Abstract, title and keywords' in Scopus, we found 413 and 526 returns, respectively. We first read the abstract, title and keywords for each paper, to check its relevance. There was some degree of overlap between the two databases in terms of papers identified and in total, 70 papers remained after this round of screening and merging. We then read the full text of the 70 papers and also checked their references for any further relevant papers that had not been identified by the search engines. This process resulted in 45 papers that met all of the inclusion criteria for the final review (see Figure 1 for the review process and Table 1 for the inclusion and exclusion criteria). A full list of the selected papers can be found in the Appendix A, classified by author name, year of publication, journal name and innovation categories. 


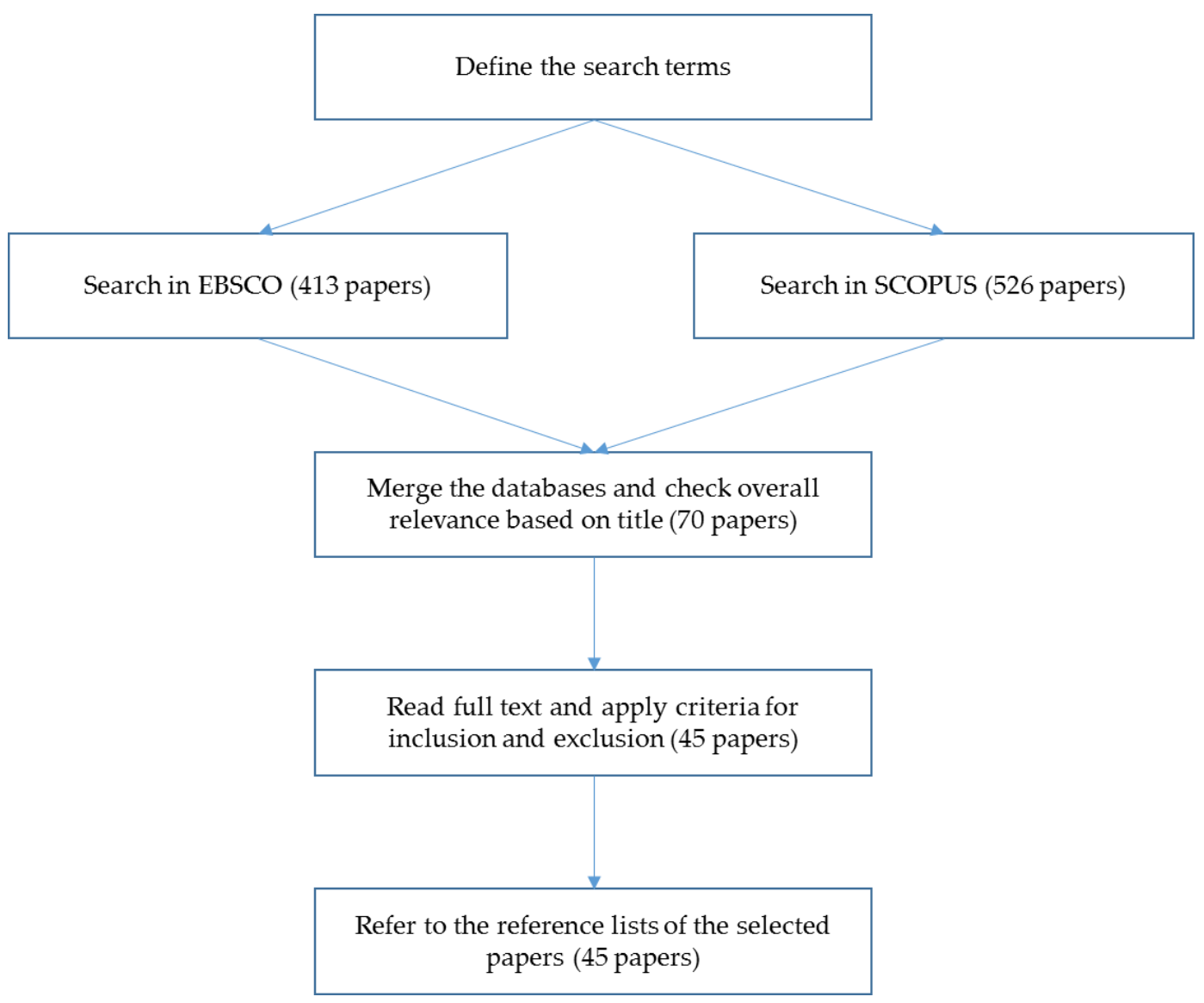

Figure 1. Literature review process.

Table 1. Inclusion and exclusion criteria in the systematic literature review.

\begin{tabular}{cc}
\hline Inclusion Criteria & Exclusion Rationale \\
\hline Focused on logistics innovation & Innovations not related to logistics \\
Focused on mainland China, Taiwan, Hong & Logistics innovations in other regions \\
Kong (Greater China Region) & Non-English language journals \\
Peer-reviewed journal paper in English & \\
An open time frame & \\
\hline
\end{tabular}

In addition, we consulted 'grey literature' such as industry reports (e.g., Fung Business Intelligence Centre [3] and Maersk Technical Report [4]). Literature reviews on logistics innovation in general were carefully examined as well, such as Grawe [17] and Busse and Wallenburg [18]. We use these documents as a point of reference in the discussion section.

\section{Descriptive Analysis}

This section presents a descriptive analysis of the 45 selected papers, including analysis of the distribution of papers by year of publication, number of papers published by the key journals, top authors, geographical region coverage, industry focus and research methodologies adopted. Figure 2 shows the distribution of papers by year, indicating that the number of papers published before 2009 generally increased. The first publication identified was published in 2002, while in 2008 and 2009, the annual number of papers reached a peak of six. After that, the number of publications stabilized at between three and five papers annually, with an exception in 2013, with only one paper. 


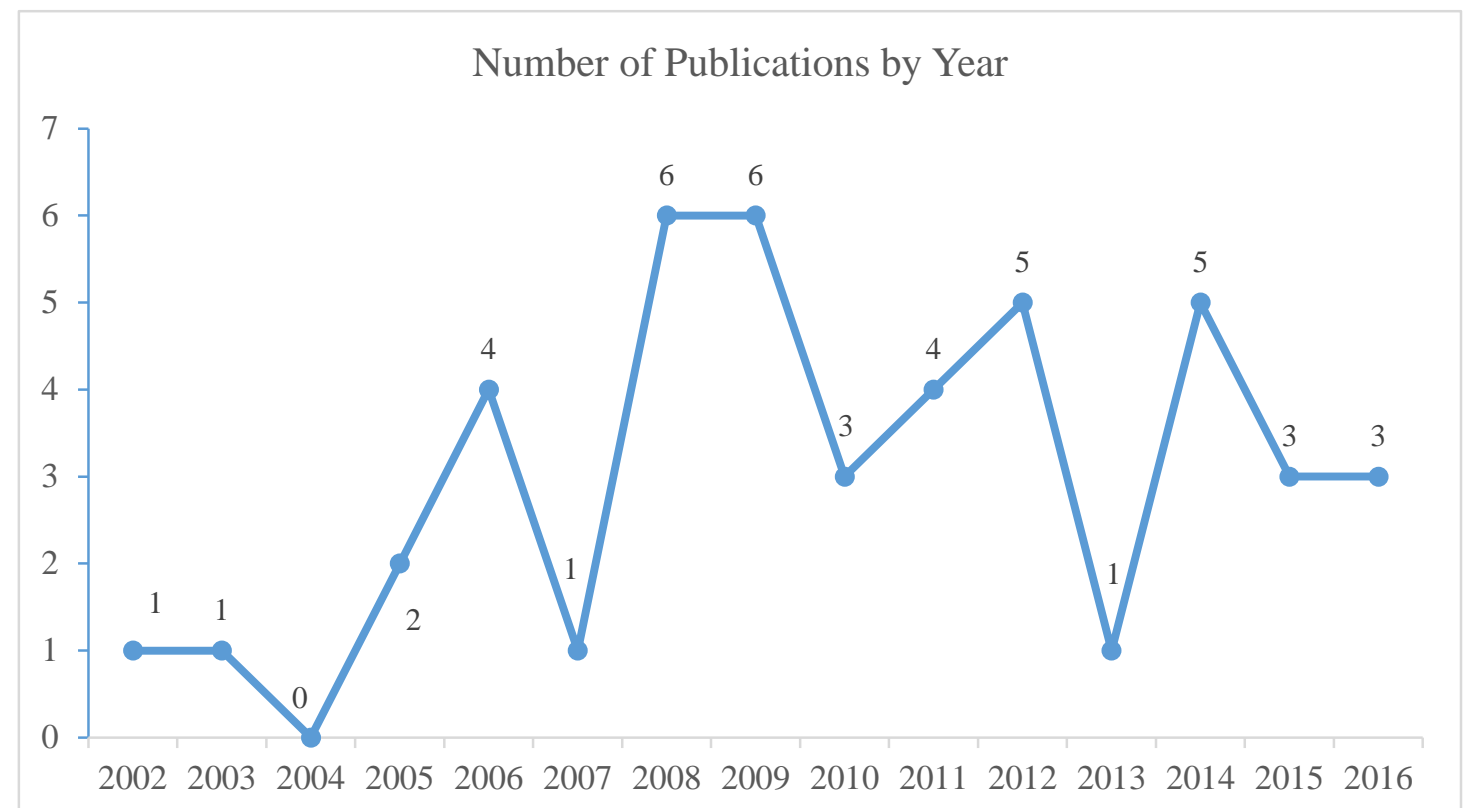

Figure 2. Number of publications by year $(\mathrm{N}=45)$.

Table 2 shows the distribution of papers by journals. In total, 28 journals published on the topic of logistics innovation in China, which shows a highly scattered distribution. International Journal of Production Economics (IJPE) has the highest number of publications with six been found, follow by International Journal of Physical Distribution \& Logistics Management (IJPDLM), and Transportation Journal (TJ) have the second highest number of publications with each publishing four. Two papers each were published by six journals and the remaining 19 journals have published one publication each.

Table 2. Number of publications by journals.

\begin{tabular}{cc}
\hline Journal Title & Number of Publications \\
\hline International Journal of Production Economics (IJPE) & 6 \\
Transportation Journal (TJ) & 4 \\
International Journal of Physical Distribution \& Logistics Management (IJPDLM) & 4 \\
The International Journal of Logistics Management (IJLM) & 2 \\
International Journal of Logistics: Research and Applications (IJLRA) & 2 \\
International Journal of Production Research (IJPR) & 2 \\
Journal of Technology Management \& Innovation (JTMI) & 2 \\
Supply Chain Management: An International Journal (SCMIJ) & 2 \\
Transportation Research Part E (TRPE) & 2 \\
Others (19) & 1 \\
Total & 45 \\
\hline
\end{tabular}

The key authors in this field were ranked in terms of their number of contributions made in the journals, as shown in Table 3. In total, 80 authors had contributed to this research topic. Of the top nine authors, only one (Nachiappan Subramanian) was based in mainland China; four were affiliated to Taiwanese universities (Chieh-Yu Lin, Yi-Hui Ho, Shong-Iee Ivan Su and Ching-Chiao Yang); two were affiliated to Swedish universities (Lianguang Cui and Susanne Hertz); and two were affiliated to Hong Kong universities (Kee-hung Lai and T.C.E. Cheng). Thus, it seemed that Taiwanese scholars and overseas Chinese were predominant in this research area. These authors were fluent in both English and Chinese, therefore having the advantage of understanding the Chinese context. 
Table 3. Number of publications by authors.

\begin{tabular}{cc}
\hline Author Name & Number of Publications \\
\hline Chieh-Yu Lin & 10 \\
Yi-Hui Ho & 5 \\
T.C.E. Cheng & 4 \\
Shong-Iee Su & 4 \\
Lianguang Cui & 3 \\
Susanne Hertz & 3 \\
Kee-hung Lai & 3 \\
Nachiappan Subramanian & 3 \\
Ching-Chiao Yang & 3 \\
Others (71) & $<3$ \\
\hline
\end{tabular}

In terms of geographic coverage of the papers, 21 out of the 45 papers focused on mainland China, 15 on Taiwan, four on Hong Kong and five on a comparison between different regions within China or between China and other countries. The predominance of Taiwanese scholars meant it was not surprising that mainland China and Taiwan received a similar amount of attention (21 papers vs. 15). Taiwanese scholars' interests are not confined to Taiwan but also to mainland China.

In terms of industry coverage, the majority of papers (34) were focused on the logistics industry, with the rest focusing on logistics issues in manufacturing, electronic manufacturing, computer, communications, consumer electronics and the high-tech, hospital, pharmaceutical and publishing industries.

In terms of the research method adopted in these papers, 33 (73.3\%) papers applied a survey method; seven applied a case study method; two applied a mixed method of survey plus case study and modelling plus case study; two applied archival data; and one used another quantitative method. It seemed that researchers tended to favor the survey method when conducting research in logistics innovation in China.

From the reviewed papers, we found that research in logistics innovation in China was still in an early stage, having only started just over a decade ago and with a limited number of key authors contributing to this emerging body of research topic. The number of papers published per year was rising slowly. We found that a similar number of papers focused on mainland China and Taiwan. It is surprising that this topic had not attracted more attention from scholars based in mainland China. The publications were mainly focused narrowly on the logistics industry, with few papers dealing with other industries.

\section{Key Themes from the Review}

This section reports the themes identified for logistics innovation in China. We developed the themes base on two previous reviews on logistics innovation literature. Grawe [17] analyses logistics innovation around three themes of antecedents, outcomes and diffusion of logistics innovation; and Busse and Wallenburg [18] separate logistics innovation into two overarching classifications: innovation management system (inputs management, knowledge management, innovation strategy, work environment, portfolio management, project management, commercialization) and innovation management processes (innovation generation, innovation adoption). These two studies use systematic literature review methods to explore logistics innovation in general and are more comprehensive than other reviews of logistics innovation, such as Flint [30] and Chapman et al. [31]. Thus, they provided a solid foundation for this research.

To guide our analysis, we combined the results of the two existing literature review papers and developed this into a new framework. We adopted the innovation management processes theme of innovation generation and innovation adoption [18], and the subthemes of antecedents and outcomes of innovation [17]. Inductively, we found three new themes: interpretation of logistics innovation, institutional environment of logistics innovation and innovation capability. 
Finally, we classified the 45 papers into five research themes, which form the basis for the subsequent sections of this part of the paper. Section 4.1 provides an interpretation of logistics innovation based on the review of the 45 papers. Section 4.2 discusses the institutional environment of general logistics innovation (the subject of nine papers). Section 4.3 focuses on innovation generation (the subject of three papers). Section 4.4 focuses on innovation adoption (the subject of 23 papers) and Section 4.5 focuses on logistics innovation capability (the subject of ten papers). In addition, the Appendix A provides a detailed classification of the themes of Section 4.2 to Section 4.5.

\subsection{Interpretation of Logistics Innovation}

The interpretation of logistics innovation included definitions and classification with regard to logistics innovation. Definitions for logistics innovation could only be found in Cui et al. [27,32] for the papers reviewed, which adopted the definition by Flint et al. [30] (p. 114) that logistics innovation is "any logistics related service from the basic to the complex that is seen as new and helpful to a particular focal audience". The rest of the papers either applied traditional innovation definitions or did not provide any definition. The definitions we reviewed could be classified broadly into three types: innovation generation; innovation adoption; and innovation generation and adoption.

In addition to these mainstream views on innovation, a capability view of innovation has emerged in recent years. For example, Daugherty et al. [15] (p. 30) define logistics service innovation capability as "a firm's ability to develop new innovative logistics services". Yang et al. [33] (p. 6) argue that innovation can be regarded as "an organizational capability because it is the act that deploys resources with a new ability to create value". Innovation capability refers to a firm's ability to transform knowledge and ideas continuously into new products, processes, and systems for the benefit of the firm [34]. Liu et al. [35] (p. 852) treat innovation as a firm-specific capability, saying, "it is the ability to develop anything new to facilitate the company's business, operation and service offerings".

In terms of logistics innovation, Busse and Wallenburg [18] suggest that the innovation literature contains three types of classification: (1) technological vs. administrative innovation; (2) product/service vs. process innovation; and (3) radical vs. incremental innovation. Lin [14,36] distinguishes between technological and administrative innovation, arguing that technological innovation pertains to products, services, and production process technology, while administrative innovation involves organizational structure and administrative processes. Over half of the papers we examined followed the first classification, with a focus on technological innovation, such as Radio-frequency identification (RFID), green practices and cloud computing. None of the reviewed papers explicitly focused on administrative innovations.

We found five papers that applied the second classification, with a focus on service innovation $[7,17,27,32,37]$. None of the papers in this review explicitly applied the third classification, which may be explained by the fact that logistics innovation tends to adopt existing innovation rather than radically generating anything completely new or disruptive to existing models [18].

\subsection{Chinese Institutional Environment for Logistics Innovation}

Papers discussing the institutional environment for logistics innovation but without a specific focus on innovation generation, adoption and/or capability were labelled 'general logistics innovation'. Out of the nine papers in this category, four explicitly discussed the institutional factors that have an influence on logistics innovation in China.

The first paper in this review, by Jiang and Prater [38], mentions that China's distribution (logistics) sector is shifting from a traditional socialist model to a free market model. However, China's distribution infrastructure and government regulations are under-developed and regional protectionism fragments distribution channels throughout China. Three main forces/trends, identified as the innovation engines to change and modernize China's distribution and logistics systems, include the booming economy, China's entry into the WTO and emergence of e-commerce (ibid). 
Daly and Cui [39] identify nine major institutional challenges to e-commerce and logistics and classify them into three types: basic (e.g., availability of information system personnel, logistics knowledge), manageable (e.g., transportation infrastructures, information system data quality) and intractable (e.g., sophisticated logistics systems, global best practice).

Lai et al. [10] discuss the institutional constraints for China's logistics development: industrial protectionism, in which highways, railways and airways are controlled by different government agencies, which lack coordination; regional protectionism, in which local governments set logistics blocks for their own benefit and charge fees to road users; and monopolistic regulations, with state-owned enterprises monopolizing sectors such as rail and freight.

Finally, Ding et al. [40] argue that the shortage of logistics human resources and the lack of logistics expertise are two key contributory factors to the operational inefficiency of the logistics industry in China.

\subsection{Innovation Generation}

Busse and Wallenburg [18] argue that innovation generation emphasizes the creative process of logistics innovation practices. We found three papers contributing to innovation generation and all of these applied the case study method.

Cui et al. [7] conduct a case study examining the way three regional TPL firms in China, Taiwan and Sweden innovate. These firms generate new service offerings according to consumers' needs, which reflect the regional characteristics.

Cui et al. [32] carry out a longitudinal single case study on an international 3PL firm, analyzing the way innovation emerges and evolves. The study suggests that both intra-organizational and inter-organizational interactions are essential in the innovation generation process, which is complicated and can be both top-down and bottom-up. This study finds that innovation at logistics firms emerges as a combination of an ad hoc response to a customer request and a purpose-driven interactive process.

Finally, Su et al. [41] conduct a longitudinal action research and explore the logistics innovation process of a Taiwanese hospital. The study presents a detailed innovation generation process at the hospital, adopting Flint et al.'s [30] four-step logistics innovation process model: activities to set the stage; activities to gather information about customers; activities involved with negotiation, clarifying and reflecting; and inter-organizational learning. It suggests that the model is not only applicable to customers but also to suppliers. Logistics innovation processes are dynamic and may improve supplier relationships; logistics innovations in the supply chain are as dependent on internal stakeholders as on external relationships; and the logistics innovation process may start out as a dialectic, conflict-ridden process and become a well-ordered, goal-oriented teleological process [30].

\subsection{Innovation Adoption}

This section discusses the antecedents and outcomes of logistics innovation adoption (also known as innovation diffusion), the topic of 23 out of the 45 papers that we studied.

\subsubsection{Antecedents of Innovation Adoption}

This topic was covered by 21 papers and the antecedents found are summarized in Table 4 under two types of factors: internal and external. Internal factors include organizational support, quality of human resources, accumulation/compatibility of technology, perceived advantage, financial resources and supply chain relationship. External factors include government support, complexity of technology, regulatory pressure, customer pressure, environmental uncertainty, and competition. Of these factors, organizational support, quality of human resources, accumulation/compatibility of technology, government support and explicitness (complexity) of technology are widely acknowledged as affecting logistics innovation, especially by Lin and his colleagues [36,42,43]. 
Table 4. Antecedents of logistics innovation adoption.

\begin{tabular}{|c|c|c|c|c|c|c|c|c|c|c|c|c|c|c|}
\hline \multirow[b]{2}{*}{ No. } & \multirow[b]{2}{*}{ Authors } & \multirow[b]{2}{*}{$\begin{array}{l}\text { Innovation } \\
\text { Focus }\end{array}$} & \multicolumn{6}{|c|}{ Internal Antecedents } & \multicolumn{6}{|c|}{ External Antecedents } \\
\hline & & & $\begin{array}{c}\text { Quality of } \\
\text { Human } \\
\text { Resources }\end{array}$ & $\begin{array}{l}\text { Organizational } \\
\text { Support }\end{array}$ & $\begin{array}{l}\text { Accumulation } \\
\text { of Technology }\end{array}$ & $\begin{array}{l}\text { Perceived } \\
\text { Advantage }\end{array}$ & $\begin{array}{l}\text { Financial } \\
\text { Resource }\end{array}$ & $\begin{array}{c}\text { Supply } \\
\text { Chain } \\
\text { Relationship }\end{array}$ & $\begin{array}{l}\text { Government } \\
\text { Support }\end{array}$ & $\begin{array}{l}\text { Complexity of } \\
\text { Technology }\end{array}$ & $\begin{array}{l}\text { Regulatory } \\
\text { Pressure }\end{array}$ & $\begin{array}{l}\text { Customer } \\
\text { Pressures }\end{array}$ & $\begin{array}{l}\text { Environmental } \\
\text { Uncertainty }\end{array}$ & Competition \\
\hline 1 & Lin [43] & Technological & $\sqrt{ }$ & $\sqrt{ }$ & & & & & $\sqrt{ }$ & $\sqrt{ }$ & & & & \\
\hline 2 & Lin [36] & Technological & $\sqrt{ }$ & $\checkmark$ & & & & & $\checkmark$ & & & & $\checkmark$ & \\
\hline 3 & Lin [14] & Technological & $\sqrt{ }$ & $\checkmark$ & $\checkmark$ & & & & $\sqrt{ }$ & $\sqrt{ }$ & & & & \\
\hline 4 & Chang et al. [51] & RFID & & & & & $\sqrt{ }$ & $\sqrt{ }$ & & v & & $\sqrt{ }$ & & $\sqrt{ }$ \\
\hline 5 & Fu et al. [53] & RFID & & & & $\checkmark$ & & & & & & $\checkmark$ & & \\
\hline 6 & $\operatorname{Lin}[54]$ & RFID & $\sqrt{ }$ & $\sqrt{ }$ & $\sqrt{ }$ & & & & $\sqrt{ }$ & $\sqrt{ }$ & & & & \\
\hline 7 & Lin [55] & RFID & $\sqrt{v}$ & 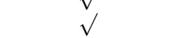 & $\checkmark$ & & & & & & & & & \\
\hline 8 & Lin and Ho [56] & RFID & $\sqrt{ }$ & $\sqrt{ }$ & $\checkmark$ & & & & $\sqrt{ }$ & $\sqrt{ }$ & & & & \\
\hline 9 & Tsai and Tang [57] & RFID & & 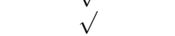 & $\checkmark$ & & $\sqrt{ }$ & & $\sqrt{ }$ & & & $\sqrt{ }$ & & \\
\hline 10 & Ho et al. [58] & Green innovation & $\sqrt{ }$ & $\sqrt{ }$ & $\sqrt{ }$ & & & & & & & & & \\
\hline 11 & Ho et al. [45] & Green innovation & $\sqrt{ }$ & $\checkmark$ & $\checkmark$ & $\checkmark$ & & & $\checkmark$ & $\sqrt{ }$ & $\sqrt{ }$ & & & \\
\hline 12 & Lai and Wong [59] & Green innovation & & & & & & & & & & $\sqrt{ }$ & & \\
\hline 13 & Lin and $\mathrm{Ho}[42]$ & Green innovation & $\sqrt{ }$ & $\sqrt{ }$ & $\checkmark$ & & & & $\sqrt{ }$ & $\sqrt{ }$ & & & $\sqrt{ }$ & \\
\hline 14 & Lin and Ho [44] & Green innovation & $\sqrt{v}$ & $\sqrt{v}$ & $\sqrt{v}$ & $\checkmark$ & & & $\sqrt{v}$ & $\sqrt[v]{v}$ & $\sqrt{ }$ & - & $\sqrt{v}$ & \\
\hline 15 & Abdulrahman et al. [48] & Reverse logistics & $\checkmark$ & $\sqrt{ }$ & $\checkmark$ & & $\sqrt{ }$ & & $\sqrt{ }$ & & $\checkmark$ & & & \\
\hline 16 & Lau and Wang [60] & Reverse logistics & & & & & & & $\sqrt{ }$ & $\checkmark$ & $\checkmark$ & & & \\
\hline 17 & Ye et al. [52] & Reverse logistics & & & & & & & & & 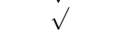 & $\sqrt{ }$ & & $\sqrt{ }$ \\
\hline 18 & Lai et al. [49] & IT & $\sqrt{ }$ & & $\checkmark$ & $\sqrt{ }$ & $\sqrt{ }$ & & & & & & & \\
\hline 19 & Lin and Lin [46] & IT & & & & $\checkmark$ & & $\sqrt{ }$ & & & & & & \\
\hline 20 & Ngai et al. [50] & IT & $\checkmark$ & & $\checkmark$ & & $\checkmark$ & & & & & & & \\
\hline 21 & Subramanian et al. [47] & Cloud computing & & & & $\sqrt{ }$ & & & & & & & & \\
\hline \multicolumn{3}{|c|}{ Total Number } & 13 & 12 & 12 & 6 & 5 & 2 & 11 & 9 & 5 & 5 & 3 & 2 \\
\hline
\end{tabular}


Perceived (relative) advantage is "the degree to which an innovation is perceived to be more advantageous than its substitute idea" [44] (p. 70). The relative advantages of green practices have had significant positive influences on the adoption [44] and infusion [45] of green practices of Chinese logistics companies. Lin and Lin [46] suggest that the perceived ease of use and usefulness of RFID directly affects the willingness to accept technology, but indirectly, this willingness affects the adoption of technology. Subramanian et al. [47] argue that the perceived environmental and cost benefits drive the need for cloud computing adoption by Chinese small- and medium-sized logistics service providers (LSPs).

Sufficient financial resource is vital for innovation adoption. Abdulrahman et al. [48] claim that a lack of initial capital and funds for return monitoring systems is one of the barriers in implementing reverse logistics in Chinese manufacturing sectors. Lai et al. [49] and Ngai et al. [50] suggest that insufficient/limited financial support is one of the top perceived barriers to the implementation of IT/IS in Hong Kong's logistics industry.

In addition, the supply chain relationship/strategy has an effect on innovation adoption. Chang et al. [51] argue that supply chain integration strategy is a critical factor influencing the adoption of RFID for the logistics industry in Taiwan. Lin and Lin [46] find that the supply chain relationship directly affects the RFID adoption behavior.

Of the external factors, regulatory pressures and customer pressures are largely found to enable green and reverse logistics adoption. Ye et al. [52] suggest that while customers have a significant positive influence on top of managers' attitude towards reverse logistics implementation, the top managers' attitude is strongly related to product recovery (the manufacturing process) but not product return (the distribution process).

Environmental uncertainty (pressure from competitors, shifting needs of customers, advanced logistics innovations) is found to have a significant influence on technology adoption for LSPs in China [36], and green innovation by LSPs in Taiwan [42].

Finally, Ye et al. [52] propose that competitors have a significant positive influence on top of managers' attitudes towards reverse logistics implementation. Chang et al. [51] claim that competition in the marketplace is a critical factor influencing the adoption of RFID in the logistics industry in Taiwan.

\subsubsection{Outcomes of Innovation Adoption}

In contrast to the large number of papers discussing the antecedents of logistics innovation adoption, only seven papers analyzed the outcomes of logistics innovation adoption. Lin [14] and Lin and Ho [56] suggest that the adoption of technological innovations and RFID improves supply chain performance, measured by both financial and non-financial indicators for the logistics industry in China.

Lai and Wong [59] claim that green logistics management positively affects both environmental and operational performance, and regulatory pressure enhances the green logistics management-performance relationships. However, Ye et al. [52] find that product return negatively affects a firm's economic performance and has no effect on environmental performance.

Tsai and Tang [57] suggest that RFID adoption has positive effects on business practices, which in turn, improve operational performance in terms of reducing tracking costs, expanding current markets, entering into new markets competitively and improving the value chain system.

Shi et al. [37] find that companies are increasingly using 3PL to provide innovative value-added services (e.g., logistics IT, supply chain financing and procurement) and the adoption of the third-party procurement service provided by 3PLs generates mutual benefits for both 3PL providers and users. Finally, Zhang et al. [61] suggest that the adoption of the Internet, the product-service system and cloud computing could enhance the logistics operation performance, decrease costs and reduce environmental pollution.

\subsection{Innovation Capability}

We found 10 papers that discussed logistics innovation capability, which is a new theme that was not found in Grawe [17] and Busse and Wallenburg [18]. The antecedents and outcomes of logistics capability are shown in Table 5 (however, because Liu et al. [35] do not discuss these factors, the total number of papers shown in the table is nine). 
Table 5. Antecedents and outcomes of logistics innovation capability.

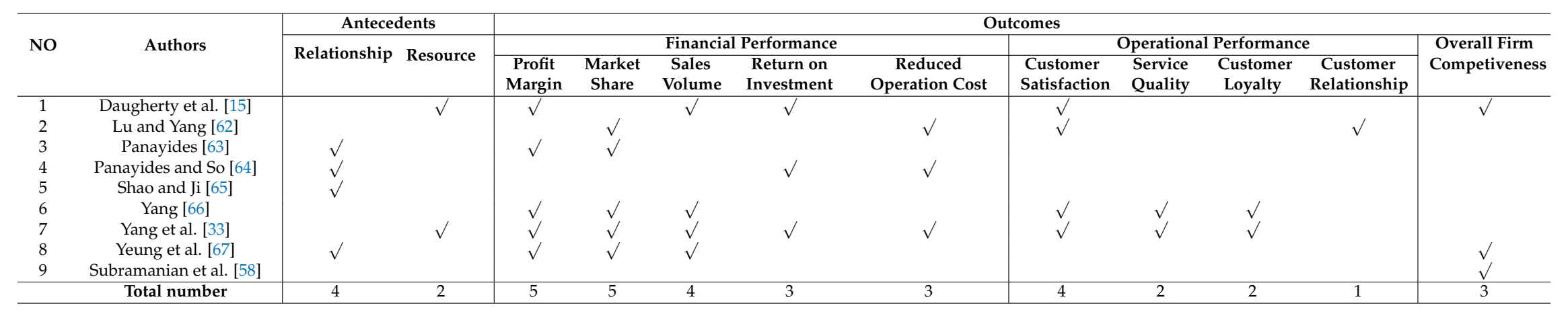




\subsubsection{Antecedents of Innovation Capability}

Four of the papers we examined noted that relationship orientation improves innovation capability. The relationship orientation is defined as "a philosophy of doing business successfully and an organizational culture that puts the buyer-seller relationship at the center of a firm's strategic and operational thinking" [64] (p. 181). Panayides and So [64] suggest that relationship orientation has a positive influence on key organizational capabilities, such as organizational learning and innovation. Organizational learning mediates between relationship orientation and logistics innovation (ibid). Panayides [63] further identifies that the LSP-client relationship leads to higher levels of innovation capability.

Yeung et al. [67] analyze the relationships among exporters' strategic orientation towards TPL providers, TPL providers' capabilities, exporters' competitive advantage and exporters' export performance. Their results show that exporters' strategic orientation towards TPL providers has a significant positive relationship with both TPL providers' basic capability and augmented innovation capability.

Shao and Ji [66] conduct research on logistics reconfiguration for the Chinese pharmaceutical industry, including both manufacturer and wholesaler. They identify that reliable 3PL provider and supplier supports are among the critical factors for the success of a reconfiguration strategy.

A further two papers discussed the relationship between resource and innovation capability. Yang et al. [33] suggest that a container shipping service firm with a high level of information equipment resources and corporate image have higher innovation capabilities and logistics service capabilities. Daugherty et al. [15] argue that organizational structure is a critical controllable internal factor for organizations to enhance service innovation capability. They propose that organizational structures are resources that exist in three forms: decentralized (centralized), formalized and specialized. They conclude that both decentralization and formalization are positively related to a firm's logistics service innovation capability, while specialization is not a significant factor because a broader base of knowledge is needed for employees.

\subsubsection{Outcomes of Innovation Capability}

With regard to outcomes, several papers found that innovation capability has a positive influence on both an organizations' financial performance (in terms of increased profit margin, growth of market share, increased sales volume, return on assets and reduced operation cost) and operational performance (in terms of customer satisfaction, service quality, customer loyalty and customer relationship). In addition, Daugherty et al. [15], Yeung et al. [67] and Subramanian et al. [68] claim that logistics innovation capability can contribute to overall firm competitiveness.

\section{Discussion}

\subsection{Proposed Conceptual Model of Logistics Innovation}

Based on the descriptive analysis and themes identified in the content analysis, we have proposed an integrated framework for logistic innovation in China (see Figure 3). In line with the dominant models in innovation literature, we see innovation as both a process and an outcome [41,69-71], in the sense that innovation generation and adoption form the reciprocal process of innovation, and innovation capability is seen as an outcome of the process. The process view stipulates that the innovation process is reflected in different forms (process or product), types (technological or administrative) and nature (radical or incremental) [71]. The existing innovation literature tends to discuss innovation generation and diffusion/adoption separately and consider adoption a stage of innovation generation, or vice versa [70]. However, the relationship between them is far from clear. Su et al. [41] claim that logistics innovation is a dynamic and conflict-ridden process but they do not explain what 'dynamic' means in the logistic innovation context. 


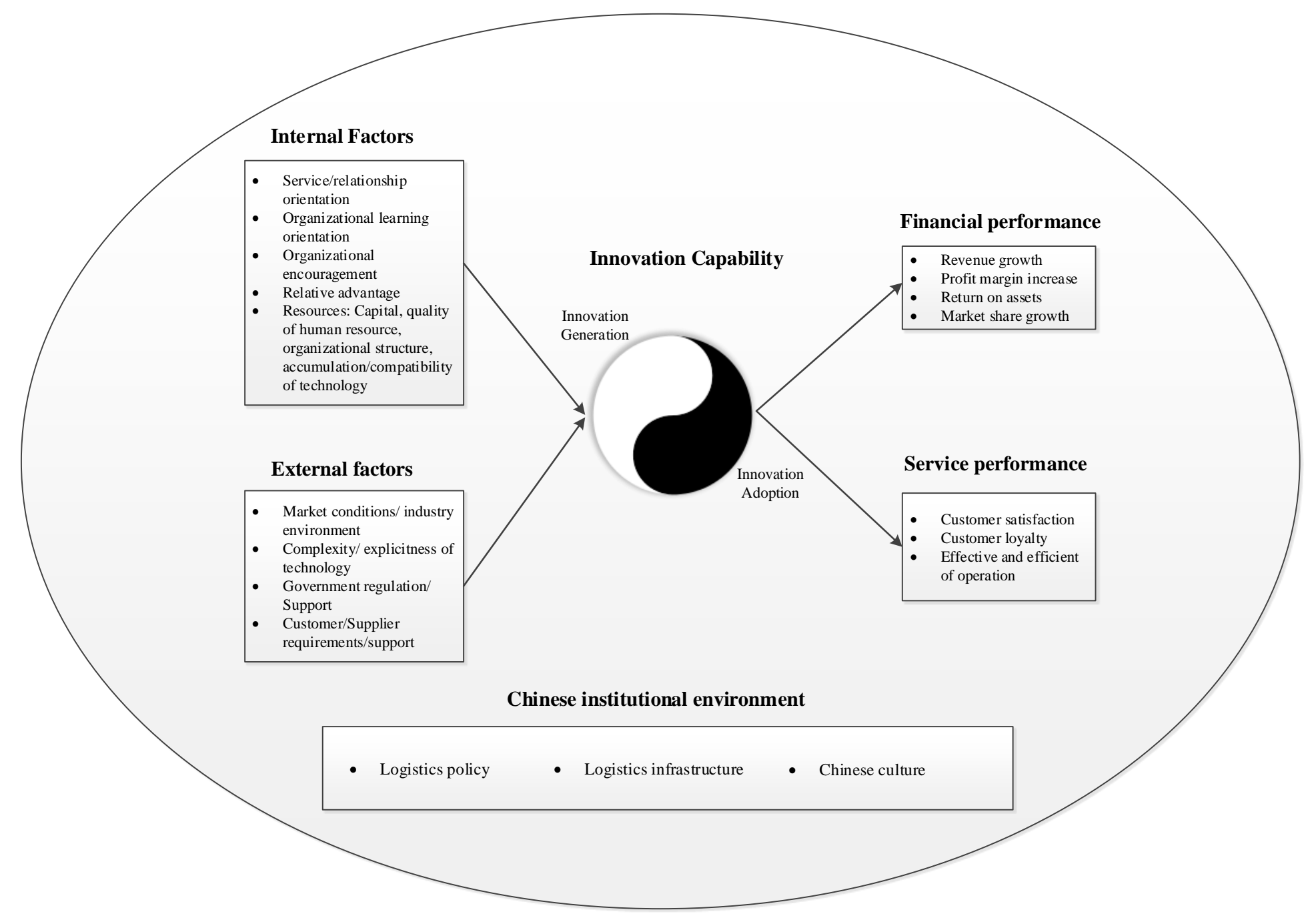

Figure 3. Proposed conceptual model of logistics innovation in China. 
Damanpour and Wischnevsky [72] point out that analytically, innovation generation can be separated from innovation adoption. Generation is described as a creative process, including the intellectually demanding "fuzzy front end" development activities and commercialization; in contrast, adoption is seen as a problem-solving process, which involves initiation, decision making and implementation (ibid).

Our conceptual model of logistics innovation was developed from a LSP perspective in China (see Figure 3). This was because approximately half of the papers we examined were focused on LSP (or 3PL), which tends to drive logistics innovation in various industries. The left-hand side Figure 3 shows the multiple factors that influence logistics innovation generation and innovation adoption, according to the literature review we conducted. These factors can generally be classified into two types: internal and external factors, drawn from the antecedents of innovation generation, adoption and capability discussed in Section 4.3 to Section 4.5. The right-hand side of Figure 3 shows that logistics innovation capability has a positive effect on both an organization's financial performance (e.g., revenue and profits) and its operational performance (e.g., customer satisfaction) $[14,15,33,56,66]$. In between these, for logistics innovation, is capability perspective; that is, logistics innovations are considered capability, which is reflected in and measured by innovation generation and innovation adoption practices [15,33].

We argue that there are capabilities required for both innovation generation and innovation adoption within a firm and that these are interrelated: in the process of logistics innovation generation, there may also be the existence of innovation adoption activities (e.g., utilizing external technology); in the innovation adoption process, external knowledge may be internalized and used for innovation generation [73].

The relationship between innovation generation and adoption shown in our conceptual model (see Figure 3) fits well with the Chinese philosophy of Daoism: in the innovation context, innovation is born from new ideas (i.e., non-being or nothing) through innovation generation, which further develops in the process of innovation adoption. As noted in the Dao-de-jing (Chapter 42) [21], "one carries two; two begets three and three begets the ten thousand things"). Here, innovation adoption is considered 'being/existence/yang', while innovation generation is considered 'non-being/yin'; that is, a pair of opposites. They complement each other and are brought together under the frame of innovation capability.

In Section 4.2, we showed that the Chinese government's policy on logistics, the development of logistics infrastructure and the Chinese culture formed the three pillars of the Chinese institutional environment, influencing both the internal and external factors affecting logistics innovation at the macro level in China. These are shown at the bottom of Figure 3.

\subsection{Future Research Direction}

Our literature review revealed that despite the importance of this topic, there seems to be a lack of research regarding logistics innovation in China in general. First, there is little understanding of the Chinese institutional environment with regard to logistics innovation. Against the backdrop of the recent turbulent global economic environment, together with the increasing costs of labor, land rent and capital expenses, it is clear that logistics innovation in China deserves more attention from researchers. The Chinese government has emphasized the importance of the logistics industry, designating it as one of the 10 restructuring and revitalization industries in 2009 [28]. Therefore, the role that the Chinese government plays in logistics innovation is worth researching as well. This is related to the logistics policy in the conceptual model shown in Figure 3. A comprehensive and up-to-date review of Chinese government policies on logistics innovation is needed to gain deeper insights into the institutional environment.

Another research area neglected by researchers and related to the Chinese institutional environment is the effect of Chinese culture on logistics innovation generation and adoption. Guanxi, the informal network based on kinship and friends, is believed to be a very effective way to mitigate 
supply relational risks [74-76] and minimize transportation problems [77]. A possible research direction could be to investigate the ways that LSPs (Western and Chinese) build their social capital (guanxi) with stakeholders of supply networks including governments, nongovernment organizations and traditional supply chain members (buyers and suppliers). The traditional Chinese wisdom provides 'sparks' to the relationship between innovation generation and adoption and is worth researching in a logistics innovation context.

Second, in terms of innovation types, we call for research on service innovation [78], as do Chapman et al. [31], who state that the logistics industry should pay more attention to innovations in logistics services. In recent years, in response to the 'last mile' challenge, e-commerce players such as Alibaba have revolutionized the logistics in the courier service industry, creating depots at the township level to cater for the demands of consumers in rural areas. New logistics service business models are emerging as a result.

Third, more attention should be given to research on the application and effects of the latest technologies on logistics such as the mobile Internet, cloud computing, big data, the Internet of Things and 3D printing: that is, the 'Internet Plus' strategy summarized by Chinese Premier Li, Keqiang in a talk published in 'Qiushi Theory', the Chinese Communist Party's official periodical [13]. The strategy aims to help the manufacturing sector optimize and better serve clients through technologies. The strategy is believed to benefit the logistics industry as well. For example, 3D printing represents the manufacturing trend towards mass customization [79] and it will bring significant changes to the organizational and supply chain structure, of which logistics is a key part. Another example is big data. Capgemini's [80] analysts declared 2013 to be the start of the 'big data era' in supply chains and big data will be an essential and integral element of future 3PL services.

It is surprising, considering the rise of the e-business market, that so little research has been conducted in this area. The rapid development of e-commerce portals started the reshaping of the logistics market by revolutionizing TPL business models (e.g., entering into the e-market) and administrative processes. Success in this rapidly growing market may depend on managing logistics [81].

More research is needed on radical innovation [61,82]. With the rapid development of the mobile Internet, logistics applications (Apps) have reached millions of customers and radical innovation could occur when large investments in the Internet and the logistics industry are made. For example, Didi started in China in 2012, providing fast, reliable, and affordable taxi services for passengers while disrupting the business model of existing taxi service providers and mobilizing the existing transport resources. Considering the fragmented nature of the inland haulage sector, it would not be surprising if a similar business model emerged in this area. In addition, it is worth noting the potential effect of blockchain in transforming the supply chain and logistics industry [83].

Finally, while logistics and supply chain uncertainly and risk management are critical topics in supply chain management, few papers on logistics innovation in China have focused on this topic $[84,85]$.

\section{Conclusions}

We conducted a content-based literature review on logistics innovation in China and identified five themes: logistics innovation, Chinese institutional environment, innovation generation, innovation adoption and innovation capability. By applying the Chinese philosophy of Daoism, we have developed a conceptual model, as shown in Figure 3. Compared with other reviews $[17,18]$, this study makes several important contributions to knowledge in this area. First, adopting a capability view, we have proposed that innovation capability is an outcome of innovation, measured and reflected in innovation generation and adoption as a reciprocal innovation process. Previous studies have considered logistics innovation as an outcome, not a process [17]; investigated innovation generation from a process perspective, emphasizing early activities [30]; and identified both innovation generation and adoption but not the intrinsic relationship between them [18]. 
Second, we have further clarified the interaction between innovation generation and adoption by using the Chinese philosophy of Daoism to explain the relationship between them as complementary opposites. This is the first study to apply the philosophy of Daoism in logistics innovation. Daoism elevates logistics innovation to a philosophical level and affords a nomological validity to innovation generation and adoption. In addition, the adoption of the philosophy of Daoism could help to increase allegiance from Chinese managers, whose cultural values are rooted in this traditional philosophy.

Third, in addition to the themes already defined by Grawe [17] and Busse and Wallenburg [18], we have identified three further themes in this area, building a complete framework of logistics innovation in China: the interpretation of logistics innovation, the Chinese institutional environment, and innovation capability.

Finally, we have proposed a number of future research directions on this topic and the practical implications for managers. In addition, the proposed conceptual model could contribute to, and has implications for, logistics innovation in general, not only confined to China.

\subsection{Implications for Practice}

This review and model development provides logistics managers with a framework of logistics innovation in China that is sensitive to cultural heritage. In the model shown in Figure 3, enabling factors (both internal and external) are identified for LSPs to understand how to enable logistics innovation. The model provides logistics managers with the outcomes of innovation that they could expect if they were to enable logistics innovation (i.e., financial and operational performance). Importantly, we have identified the mechanisms through which logistics innovation can take place (i.e., the dynamic transition between innovation generation and innovation adoption), helping managers understand the way logistics innovation can be generated and adopted. For managers wishing to promote logistics innovation in China, the cultural context must be considered and leveraged to achieve an effective outcome.

\subsection{Limitations of the Research}

Our research has several limitations. First, we developed our conceptual framework based on the antecedents, outcomes and macro-level factors identified by 45 journal articles; some factors could have been neglected by these researchers. Second, for the convenince of comminucation we examined only articles in the English language, excluding studies published in the Chinese language, which may provide some insights. Finally, we developed our conceptual framework by adopting the philosophy of Daoism; however, other philosophical principles could be explored in the future.

Author Contributions: Y.G. and F.J. initiated the idea and wrote the paper together. L.C. and R.W. contributed to the idea development and the revision of the paper.

Funding: We acknowledge financial support from The Ministry of Education of Humanities and Social Sciences project (Grant number: 17YJA630034) and the Natural Science Foundation of Fujian Province of China (No. 2017J01519).

Conflicts of Interest: There is no conflict of interest identified for the research. 


\section{Appendix A.}

Table A1. Overview of the Reviewed Papers, Organized by Author Name and Year.

\begin{tabular}{|c|c|c|c|c|}
\hline NO & Authors & Year & Journal & Category \\
\hline 1 & Abdulrahman et al. [48] & 2014 & International Journal of Production Economics & Innovation adoption \\
\hline 2 & Chang et al. [51] & 2008 & Communications of the Association for Information Systems & Innovation adoption \\
\hline 3 & Cui et al. [7] & 2009 & Transportation Journal & Innovation generation \\
\hline 4 & Cui et al. [32] & 2010 & Journal of Transport and Supply Chain Management & Innovation generation \\
\hline 5 & Cui et al. [27] & 2012 & Transportation Journal & General innovation \\
\hline 6 & Daly and Cui [39] & 2003 & Industrial Marketing Management & General innovation \\
\hline 7 & Daugherty et al. [15] & 2011 & The International Journal of Logistics Management & Innovation capability \\
\hline 8 & Ding et al. [40] & 2015 & International Journal of Production Research & General innovation \\
\hline 9 & Fu et al. [53] & 2015 & The International Journal of Logistics Management & Innovation adoption \\
\hline 10 & Ho et al. [58] & 2009 & International Journal of Organizational Innovation & Innovation adoption \\
\hline 11 & Ho et al. [45] & 2014 & Journal of Economics and Social Studies & Innovation adoption \\
\hline 12 & Huang and Yang [86] & 2014 & Management Research Review & General innovation \\
\hline 13 & Jiang and Prater [38] & 2002 & $\begin{array}{c}\text { International Journal of Physical Distribution \& Logistics } \\
\text { Management }\end{array}$ & General innovation \\
\hline 14 & Lai and Wong [59] & 2012 & Omega & Innovation adoption \\
\hline 15 & Lai et al. [49] & 2005 & Transportation Journal & Innovation adoption \\
\hline 16 & Lai et al. [10] & 2008 & Journal of Supply Chain Management & General innovation \\
\hline 17 & Lau and Wang [60] & 2009 & Supply Chain Management: An International Journal & Innovation adoption \\
\hline 18 & Lin [43] & 2006 & The Journal of American Academy of Business & Innovation adoption \\
\hline 19 & Lin [36] & 2007 & Journal of Technology Management in China & Innovation adoption \\
\hline 20 & Lin [54] & $2008 \mathrm{a}$ & International Journal of Management & Innovation adoption \\
\hline 21 & Lin [55] & 2009 & Journal of Technology Management \& Innovation & Innovation adoption \\
\hline 22 & Lin $[14]$ & $2008 b$ & $\begin{array}{c}\text { International Journal of Technology Management and } \\
\text { Sustainable Development }\end{array}$ & Innovation adoption \\
\hline 23 & Lin and Ho [42] & 2008 & Journal of Technology Management \& Innovation & Innovation adoption \\
\hline 24 & Lin and Ho [56] & 2009 & Supply Chain Management: An International Journal & Innovation adoption \\
\hline 25 & Lin and Ho [58] & 2011 & Journal of Business Ethics & Innovation adoption \\
\hline 26 & Lin and Lin [46] & 2014 & International Journal of Electronic Business Management & Innovation adoption \\
\hline 27 & Liu [87] & 2011 & $\begin{array}{l}\text { International Journal of Logistics: Research and } \\
\text { Applications }\end{array}$ & General innovation \\
\hline 28 & Liu et al. [35] & 2010 & $\begin{array}{c}\text { International Journal of Physical Distribution \& Logistics } \\
\text { Management }\end{array}$ & Innovation capability \\
\hline 29 & Lu and Yang [62] & 2010 & The Service Industrial Journal & Innovation capability \\
\hline 30 & Ngai et al. [50] & 2008 & International Journal of Production Economics & Innovation adoption \\
\hline 31 & Panayides [63] & 2006 & European Journal of Innovation Management & Innovation capability \\
\hline 32 & Panayides and So [64] & 2005 & Transportation Research Part E & Innovation capability \\
\hline 33 & Shao and Ji [65] & 2006 & Transportation Journal & Innovation capability \\
\hline 34 & Shi et al. [37] & 2015 & International Journal of Production Economics & Innovation adoption \\
\hline 35 & Su et al. [41] & 2011 & $\begin{array}{l}\text { International Journal of Physical Distribution \& Logistics } \\
\text { Management }\end{array}$ & Innovation generation \\
\hline 36 & Subramanian et al. [47] & 2014 & Transportation Research Part E & Innovation adoption \\
\hline 37 & Subramanian et al. [68] & 2016 & Industrial Management \& Data Systems & Innovation capability \\
\hline 38 & Tsai and Tang [57] & 2012 & Journal of Engineering and Technology Management & Innovation adoption \\
\hline 39 & Wang and Xiao [88] & 2015 & Journal of Transport Geography & General innovation \\
\hline 40 & Wu and Cheng [89] & 2006 & $\begin{array}{c}\text { International Journal of Physical Distribution \& Logistics } \\
\text { Management }\end{array}$ & General innovation \\
\hline 41 & Yang [66] & 2012 & $\begin{array}{c}\text { International Journal of Logistics: Research and } \\
\text { Applications }\end{array}$ & Innovation capability \\
\hline 42 & Yang et al. [33] & 2009 & International Journal of Production Economics & Innovation capability \\
\hline 43 & Ye et al. [52] & 2013 & International Journal of Production Economics & Innovation adoption \\
\hline 44 & Yeung et al. [67] & 2012 & International Journal of Production Economics & Innovation capability \\
\hline 45 & Zhang et al. [61] & 2016 & International Journal of Production Research & Innovation adoption \\
\hline
\end{tabular}

\section{References}

1. Circular on the Operation of National Logistics in 2015. NDRC. Available online: http:/ /stock.sohu.com/ 20160531/n452209939.shtml (accessed on 25 September 2016). (In Chinese)

2. State Council on Printing and Distributing the Development of the Logistics Industry Medium and Long-term Planning (2014-2020). State Council. Available online: http:/ /www.gov.cn/zhengce/content/2014-10/04/ content_9120.htm (accessed on 12 February 2017). (In Chinese)

3. Logistics Industry in China, Fung Business Intelligence Centre. Available online: http:/ /www.funggroup. com/eng/knowledge/research/china_dis_issue113.pdf (accessed on 8 May 2015). 
4. Bang, J.K.; Greve, M.; Westergaard-Kabelmann, T. A leading trade nation: The role of container shipping and logistics in enhancing trade and economic growth in China. Available online: http:/ /www.maersk.com/ \{\}/ media/the\%20maersk\%20group/sustainability/files/maersk-china-study-technical-report-2014.pdf?la=en (accessed on 19 September 2015).

5. Tan, A.W.K.; Zhao, Y.; Zhang, D.; Hilmola, O.P. State of third party logistics providers in China. Ind. Manag. Data Syst. 2014, 114, 1322-1343.

6. Wang, X.; Lai, F.; Wang, Q.; Zantow, K. Strategic postures of third-party logistics providers in mainland China. Int. J. Phys. Distrib. Logist. Manag. 2006, 36, 793-819. [CrossRef]

7. Cui, L.; Shong-Lee, I.S.; Hertz, S. How do regional third-party logistics firms innovate? A cross-regional study. Transp. J. 2009, 48, 44-50.

8. Metters, R.; Zhao, X.; Bendoly, E.; Jiang, B.; Young, S. The way that can be told of is not an unvarying way: Cultural impacts on operations management in Asia. J. Oper. Manag. 2010, 28, 177-185. [CrossRef]

9. Zhao, X.; Flynn, B.B.; Rothm, A.V. Decision sciences research in China: A critical review and research agenda-Foundations and overview. Decis. Sci. 2006, 37, 451-496. [CrossRef]

10. Lai, F.; Li, D.; Wang, Q.; Zhao, X. The information technology capability of third-party logistics providers: A resource-based view and empirical evidence from China. J. Supply Chain Manag. 2008, 44, 22-38. [CrossRef]

11. Miao, Z.; Cai, S.; Xu, D. Exploring the antecedents of logistics social responsibility: A focus on Chinese firms. Int. J. Prod. Econ. 2012, 140, 18-27. [CrossRef]

12. Barney, J.B.; Dagnino, G.B.; Corte, V.D.; Tsang, E.W.K. Management and organization review special issue 'Coopetition and innovation in transforming economies'. Manag. Organ. Rev. 2017, 13, 201-204. [CrossRef]

13. Li, K. Spawned new momentum, achieve development and upgrading. Qiushi Theory. Available online: http:/ / www.qstheory.cn/dukan/qs/2015-10/15/c_1116807989.htm (accessed on 26 October 2015). (In Chinese)

14. Lin, C.Y. Determinants of the adoption of technological innovations by logistics service providers in China. Int. J. Technol. Manag. Sustain. Dev. 2008, 7, 19-38. [CrossRef]

15. Daugherty, P.J.; Chen, H.; Ferrin, B.G. Organizational structure and logistics service innovation. Int. J. Logist. Manag. 2011, 22, 26-51. [CrossRef]

16. Liu, X.; Mckinnon, A.C. Theory development in China-based supply chain management research: A literature review. Int. J. Logist. Manag. 2016, 27, 972-1001. [CrossRef]

17. Grawe, S.J. Logistics innovation: A literature-based conceptual framework. Int. J. Logist. Manag. 2009, $20,360-377$. [CrossRef]

18. Busse, C.; Wallenburg, C.M. Innovation management of logistics service providers: Foundations, review, and research agenda. Int. J. Phys. Distrib. Logist. Manag. 2011, 41, 187-218. [CrossRef]

19. Jiang, B.; Frazier, G.V.; Heiser, D. China-related POM research: A literature review and suggestions for future research. Int. J. Oper. Prod. Manag. 2007, 27, 662-684. [CrossRef]

20. Tian, Q. Perception of business bribery in China: The impact of moral philosophy. J. Bus. Ethics 2008, 80, 437-445. [CrossRef]

21. Yao, Z. Typology of nothing: Heidegger, Daoism and Buddhism. Comput. Philos. 2010, 1, 78-89. [CrossRef]

22. Birkin, F.; Cashman, A.; Koh, S.C.L.; Liu, Z. New sustainable business models in China. Bus. Strategy Environ. 2009, 18, 64-77. [CrossRef]

23. Sabelli, H. The union of opposites: From Taoism to process theory. Syst. Res. Behav. Sci. 1998, 15, $429-441$. [CrossRef]

24. Strutton, D.; Pelton, L. Scaling the great wall: The yin and yang of resolving business conflicts in China. Bus. Horiz. 1997, 40, 22-35. [CrossRef]

25. Seuring, S.; Gold, S. Conducting content-analysis based literature reviews in supply chain management. Supply Chain Manag. Int. J. 2012, 17, 544-555. [CrossRef]

26. Jia, F.; Lamming, R.; Sartor, M.; Orzes, G.; Nassimbeni, G. Global purchasing strategy and international purchasing offices: Evidence from case studies. Int. J. Prod. Econ. 2014, 154, 284-298. [CrossRef]

27. Cui, L.; Su, S.I.I.; Hertz, S. Logistics innovation in China. Transp. J. 2012, 51, 98-117.

28. Liu, X. China-based logistics research: A review of the literature and implications. Int. J. Phys. Distrib. Logist. Manag. 2014, 44, 392-411. [CrossRef]

29. Mena, C.; Christopher, M.; Johnson, M.; Jia, F. Innovation in Logistics Services; Cranfield University School of Management: Bedford, UK, 2007. 
30. Flint, D.J.; Larsson, E.; Gammelgaard, B.; Mentzer, J.T. Logistics innovation: A customer value-oriented social process. J. Bus. Logist. 2005, 26, 113-147. [CrossRef]

31. Chapman, R.L.; Soosay, C.; Kandampully, J. Innovation in logistic services and the new business model: A conceptual framework. Int. J. Phys. Distrib. Logist. Manag. 2002, 33, 630-650. [CrossRef]

32. Cui, L.; Hertz, S.; Su, S.I.I. Innovation in an international third party logistics firm: A strategy-as-practice perspective. J. Transp. Supply Chain Manag. 2010, 4, 69-88. [CrossRef]

33. Yang, C.C.; Marlow, P.B.; Lu, C.S. Assessing resources, logistics service capabilities, innovation capabilities and the performance of container shipping services in Taiwan. Int. J. Prod. Econ. 2009, 122, 4-20. [CrossRef]

34. Hurley, R.F.; Hult, G.T.M. Innovation, market orientation, and organizational learning: An integration and empirical examination. J. Mark. 1998, 62, 42-54. [CrossRef]

35. Liu, X.; Grant, D.B.; Mckinnon, A.C.; Feng, Y. An empirical examination of the contribution of capabilities to the competitiveness of logistics service providers: A perspective from China. Int. J. Phys. Distrib. Logist. Manag. 2010, 40, 847-866. [CrossRef]

36. Lin, C.Y. Factors affecting innovation in logistics technologies for logistics service providers in China. J. Technol. Manag. China 2007, 2, 22-37. [CrossRef]

37. Shi, Y.; Zhang, A.; Arthanari, T.; Liu, Y.; Cheng, T.C.E. Third-party purchase: An empirical study of third-party logistics providers in China. Int. J. Prod. Econ. 2016, 171, 189-200. [CrossRef]

38. Jiang, B.; Prater, E. Distribution and logistics development in China. Int. J. Phys. Distrib. Logist. Manag. 2015, 32, 783-798. [CrossRef]

39. Daly, S.P.; Cui, L.X. E-logistics in China: Basic problems, manageable concerns and intractable solutions. Ind. Mark. Manag. 2003, 32, 235-242. [CrossRef]

40. Ding, M.J.; Kam, B.H.; Zhang, J.Y.; Jie, F. Effects of human resource management practices on logistics and supply chain competencies: Evidence from China logistics service market. Int. J. Prod. Res. 2015, 53, 2885-2903. [CrossRef]

41. Su, S.I.I.; Gammelgaard, B.; Yang, S.L. Logistics innovation process revisited: Insights from a hospital case study. Int. J. Phys. Distrib. Logist. Manag. 2011, 41, 577-600.

42. Lin, C.Y.; Ho, Y.H. An empirical study on logistics service providers' intention to adopt green innovations. J. Technol. Manag. Innov. 2008, 3, 17-26.

43. Lin, C.Y. Influencing factors on the innovation in logistics technologies for logistics service providers in Taiwan. J. Am. Acad. Bus. 2006, 9, 257-263.

44. Lin, C.Y.; Ho, Y.H. Determinants of green practice adoption for logistics companies in China. J. Bus. Ethics 2011, 98, 67-83. [CrossRef]

45. Ho, Y.H.; Lin, C.Y.; Tsai, J.S. An empirical study on organizational infusion of green an empirical study on organizational infusion of green practices in Chinese logistics companies. J. Econ. Soc. Stud. 2014, 4, 159-189. [CrossRef]

46. Lin, T.H.; Lin, I. Factors for information technology acceptance willingness and adoption in logistics industry from supply chain perspectives. Int. J. Electron. Bus. Manag. 2014, 12, 167-176.

47. Subramanian, N.; Abdulrahman, M.D.; Zhou, X. Integration of logistics and cloud computing service providers: Cost and green benefits in the Chinese context. Transp. Res. Part E 2014, 70, 86-98. [CrossRef]

48. Abdulrahman, M.D.; Gunasekaran, A.; Subramanian, N. Critical barriers in implementing reverse logistics in the Chinese manufacturing sectors. Int. J. Prod. Econ. 2014, 147, 460-471. [CrossRef]

49. Lai, K.H.; Ngai, E.W.T.; Cheng, T.C.E. Information technology adoption in Hong Kong's logistics industry. Transp. J. 2005, 44, 1-9.

50. Ngai, E.W.T.; Lai, K.H.; Cheng, T.C.E. Logistics information systems: The Hong Kong experience. Int. J. Prod. Econ. 2008, 113, 223-234. [CrossRef]

51. Chang, S.I.; Hung, S.Y.; Yen, D.C.; Chen, Y.J. The determinants of RFID adoption in the logistics industry: A supply chain management perspective. Commun. Assoc. Inf. Syst. 2008, 23, 197-218. [CrossRef]

52. Ye, F.; Zhao, X.; Prahinski, C.; Li, Y. The impact of institutional pressures, top managers' posture and reverse logistics on performance: Evidence from China. Int. J. Prod. Econ. 2013, 143, 132-143. [CrossRef]

53. Fu, H.P.; Chang, T.H.; Lin, A.; Du, Z.J.; Hsu, K.Y. Key factors for the adoption of RFID in the logistics industry in Taiwan. Int. J. Logist. Manag. 2015, 26, 61-81. [CrossRef]

54. Lin, C.Y. Factors affecting the adoption of radio frequency identification technology by logistics service providers: An empirical study. Int. J. Manag. 2008, 25, 488-593. 
55. Lin, C.Y. An empirical study on organizational determinants of RFID adoption in the logistics industry. J. Technol. Manag. Innov. 2009, 4, 1-7. [CrossRef]

56. Lin, C.Y.; Ho, Y.H. RFID technology adoption and supply chain performance: An empirical study in China's logistics industry. Supply Chain Manag. Int. J. 2009, 14, 369-378. [CrossRef]

57. Tsai, W.C.; Tang, L.L. A model of the adoption of radio frequency identification technology: The case of logistics service firms. J. Eng. Technol. Manag. 2012, 29, 131-151. [CrossRef]

58. Ho, Y.H.; Lin, C.Y.; Chiang, S.H. Organizational determinants of green innovation implementation in the logistics industry. Int. J. Organ. Innov. 2009, 2, 3-12.

59. Lai, K.H.; Wong, C.W.Y. Green logistics management and performance: Some empirical evidence from Chinese manufacturing exporters. Omega 2012, 40, 267-282. [CrossRef]

60. Lau, K.H.; Wang, Y. Reverse logistics in the electronic industry of China: A case study. Supply Chain Manag. Int. J. 2009, 14, 447-465.

61. Zhang, Y.; Liu, S.; Liu, Y.; Li, R. Smart box-enabled product- service system for cloud logistics. Int. J. Prod. Res. 2016, 54, 6693-6706. [CrossRef]

62. Lu, C.S.; Yang, C.C. Logistics service capabilities and firm performance of international distribution center operators. Serv. Ind. J. 2010, 30, 281-298. [CrossRef]

63. Panayides, P.M. Enhancing innovation capability through relationship management and implications for performance. Eur. J. Innov. Manag. 2006, 9, 466-483. [CrossRef]

64. Panayides, P.M.; So, M. Logistics service provider-client relationships. Transp. Res. Part E 2005, 41, 179-200. [CrossRef]

65. Shao, X.; Ji, J. Reconfiguration of pharmaceutical logistics operations in China: An empirical study. Transp. J. 2006, 45, 52-66.

66. Yang, C. Assessing the moderating effect of innovation capability on the relationship between logistics service capability and firm performance for ocean freight forwarders. Int. J. Logist. Res. Appl. 2012, 15, 53-69. [CrossRef]

67. Yeung, K.; Zhou, H.; Yeung, A.C.L.; Cheng, T.C.E. The impact of third-party logistics providers' capabilities on exporters' performance. Int. J. Prod. Econ. 2012, 135, 741-753. [CrossRef]

68. Subramanian, N.; Gunasekaran, A.; Papadopoulos, T.; Nie, P. 4th party logistics service providers and industrial cluster competitiveness: Collaborative operational capabilities framework. Ind. Manag. Data Syst. 2016, 116, 1303-1330. [CrossRef]

69. Stephan, M.W. Innovation management in the German transportation industry. J. Bus. Logist. 2008, 29, $215-231$.

70. Damanpour, F.; Aravind, D. Managerial innovation: Conceptions, processes and antecedents. Manag. Organ. Rev. 2012, 8, 423-454. [CrossRef]

71. Crossan, M.M.; Apaydin, M. A multi-dimensional framework of organizational innovation: A systematic review of the literature. J. Manag. Stud. 2010, 47, 1154-1191. [CrossRef]

72. Damanpour, F.; Wischnevsky, J.D. Research on innovation in organizations: Distinguishing innovation-generating from innovation-adopting organizations. J. Eng. Technol. Manag. 2006, 23, $269-291$. [CrossRef]

73. Nonaka, I.; Takeuchi, H. The Knowledge Creating Company: How Japanese Companies Create the Dynamics of Innovation; Oxford University Press: New York, NY, USA, 1995.

74. Jia, F.; Zsidisin, G.A. Supply relational risk: What role does guanxi play? J. Bus. Logist. 2014, 35, $259-267$. [CrossRef]

75. Jia, F.; Rutherford, C. Mitigation of supply chain relational risk caused by cultural differences between China and the West. Int. J. Logist. Manag. 2010, 21, 251-270. [CrossRef]

76. Jia, F.; Lamming, R. Cultural adaptation in Chinese-Western supply chain partnerships. Int. J. Oper. Prod. Manag. 2013, 33, 528-561. [CrossRef]

77. Ta, H.P.; Choo, H.L.; Sum, C.C. Transportation concerns of foreign firms in China. Int. J. Phys. Distrib. Logist. Manag. 2000, 30, 35-54. [CrossRef]

78. Rubalcaba, L.; Gallego, J.; Hipp, C.; Williams, C.C. Services and organisational innovation: The right mix for value creation. Manag. Decis. 2013, 51, 1117-1134.

79. Jia, F.; Wang, X.; Mustafee, N.; Hao, L. Investigating the feasibility of supply chain-centric business models in 3D chocolate printing: A simulation study. Technol. Forecast. Soc. Chang. 2016, 102, 202-213. [CrossRef] 
80. Capgemini: Third-Party Logistics Study: The State of Logistics Outsourcing. Available online: https://www. capgemini.com/resources/2014-third-party-logistics-study-the-state-of-logistics-outsourcing (accessed on 25 October 2015).

81. Koh, M.F.; Gan, C.W. China's E-Commerce Market in 2014: The Logistics Challenges; A.T. Kearney: Chicago, IL, USA, 2015; Available online: https:/ / www.atkearney.com/documents / (accessed on 28 October 2015).

82. Germain, R. The role of context and structure in radical and incremental logistics innovation adoption. J. Bus. Res. 1996, 35, 117-127. [CrossRef]

83. Marr, B. How Blockchain will Transform the Supply Chain and Logistics Industry, Forbes. Available online: https:/ /www.forbes.com/sites/bernardmarr/2018/03/23/how-blockchain-will-transform-thesupply-chain-and-logistics-industry/\#51487ea85fec (accessed on 15 September 2018).

84. Fera, M.; Fruggiero, F.; Lambiase, A.; Macchiaroli, R.; Miranda, S. The role of uncertainty in supply chains under dynamic modeling. Int. J. Ind. Eng. Comput. 2017, 8, 119-140. [CrossRef]

85. Martino, G.; Fera, M.; Iannone, R.; Miranda, S. Supply chain risk assessment in the fashion retail industry: An analytic network process approach. Int. J. Appl. Eng. Res. 2017, 12, 140-154.

86. Huang, Y.C.; Yang, M.L. Reverse logistics innovation, institutional pressures and performance. Manag. Res. Rev. 2014, 37, 615-641. [CrossRef]

87. Liu, X. Competitiveness of logistics service providers: A cross-national examination of management practices in China and the UK. Int. J. Logist. Res. Appl. 2011, 14, 251-269. [CrossRef]

88. Wang, J.J.; Xiao, Z. Co-evolution between etailing and parcel express industry and its geographical imprints: The case of China. J. Transp. Geogr. 2015, 46, 20-34. [CrossRef]

89. Wu, Y.C.J.; Cheng, W.P. Reverse logistics in the publishing industry: China, Hong Kong, and Taiwan. Int. J. Phys. Distrib. Logist. Manag. 2006, 36, 507-523.

(C) 2019 by the authors. Licensee MDPI, Basel, Switzerland. This article is an open access article distributed under the terms and conditions of the Creative Commons Attribution (CC BY) license (http://creativecommons.org/licenses/by/4.0/). 